\title{
Floristic composition and similarity of 15 hectares in Central Amazon, Brazil
}

\author{
Kátia Emidio da Silva*1, Sebastião Venancio Martins², Carlos Antonio Alvares Soares Ribeiro ${ }^{2}$, \\ Nerilson Terra Santos ${ }^{3}$, Celso Paulo de Azevedo ${ }^{4}$, Francisca Dionizia de Almeida Matos ${ }^{5} \&$ Ieda \\ Leão do $\mathrm{Amaral}^{5}$ \\ 1. Brazilian Agricultural Research Corporation, Embrapa Amazonia Ocidental, rodovia AM010, PO Box 319, post code \\ 69010-970, Manaus, Amazonas, Brazil; kat.emidio@gmail.com \\ 2. Federal University of Viçosa, UFV, Forestry Engineering Department, Av. Ph Rolfs s/n, post code 36570-000, Viçosa, \\ Minas Gerais, Brasil; venancio@ufv.br, cribeiro@ufv.br \\ 3. Federal University of Viçosa, UFV, Department of Statistics, Av. Ph Rolfs s/n, post code 36570-000,Viçosa, Minas \\ Gerais,Brazil; nsantos@ufv.br \\ 4. Embrapa Amazonia Ocidental, rodovia AM010, C.P.319, post code: 69010-970, Manaus, Amazonas, Brazil; celso. \\ azevedo@cpaa.embrapa.br \\ 5. Instituto Nacional de Pesquisas da Amazonia, INPA/CPBO, av. Andre Araújo, Aleixo, post code 69060-001, Manaus, \\ Amazonas, Brasil; fmatos@inpa.gov.br, iamaral@inpa.gov.br \\ * Corresponding author
}

\section{Received 10-VIII-2010. C Corrected 10-II-2011. Accepted 15-III-2011.}

\begin{abstract}
The Amazon region is one of the most diverse areas in the world. Research on high tropical forest diversity brings up relevant contributions to understand the mechanisms that result and support such diversity. In the present study we describe the species composition and diversity of 15 one-ha plots in the Amazonian terra firme dense forest in Brazil, and compare the floristic similarity of these plots with other nine one-ha plots. The 15 plots studied were randomly selected from permanent plots at the Embrapa Experimental site, Amazonas State in 2005. The diversity was analysed by using species richness and Shannon's index, and by applying the Sorensen's index for similarity and unweighted pair-group average (UPGMA) as clustering method. Mantel test was performed to study whether the differences in species composition between sites could be explained by the geographic distance between them. Overall, we identified 8771 individuals, 264 species and 51 plant families. Most of the species were concentrated in few families and few had large number of individuals. Families presenting the highest species richness were Fabaceae (Faboideae: 22spp., Mimosoideae: 22spp.), Sapotaceae: 22spp., Lecythidaceae: 15 and Lauraceae: 13. Burseraceae had the largest number of individuals with $11.8 \%$ of the total. The ten most abundant species were: Protium hebetatum (1 037 individuals), Eschweilera coriacea (471), Licania oblongifolia (310), Pouteria minima (293), Ocotea cernua (258), Scleronema micranthum (197), Eschweilera collina (176), Licania apelata (172), Naucleopsis caloneura (170) and Psidium araca (152), which represented $36.5 \%$ of all individuals. Approximately $49 \%$ of species had up to ten individuals and $13 \%$ appeared only once in all sampled plots, showing a large occurrence of rare species. Our study area is on a forest presenting a high tree species diversity with Shannon's diversity index of 4.49. The dendrogram showed two groups of plots with low similarity between them (less than 0.25 ), and the closer the plots were one to another, more similar in species composition (Mantel $\mathrm{R}=0.3627, \mathrm{p}<0.01$ ). The 15 plots in our study area share more than $50 \%$ of their species composition and represent the group of plots that have the shortest distance between each other. Overall, our results highlight the high local and regional heterogeneity of environments in terra firme forests, and the high occurrence of rare species, which should be considered in management and conservation programs in the Amazon rainforest, in order to maintain its structure on the long run. Rev. Biol. Trop. 59 (4): 1927-1938. Epub 2011 December 01.
\end{abstract}

Key words: forest composition, Central Amazonian, forest ecology, floristic similarity, diversity, terra firme, upland dense forest. 
Brazil holds approximately one third of the remaining world's tropical forests being one of the most important biodiversity areas (PAS 2008), and with the most complex natural environments on Earth. In the Amazon region several landscapes are formed by a mosaic of areas with variable occurrence of plant species per environment (Pitman et al. 2001), and where the differences in tree species distribution can be attributed to habitat peculiarities and/or species' preferences. Under this context, there has been a rising interest among scientists and societies around the world, especially in what concerns biodiversity loss due to deforestation, regional and global climate changes, and to how species and communities behave when under such changes (Houghton et al. 2000).

The Brazilian Amazon region occupies over half of all Brazilian territory and approximately $65 \%$ of its vegetation cover is classified as terra firme forests, which is characterized by high tree species diversity, presenting a low number of individuals, high floristic dissimilarity among adjacent plots, with large variation in floristic similarity (10-36\%) (Prance et al. 1976, Ferreira \& Prance 1998, Lima Filho et al. 2001, ter Steege et al. 2006, Oliveira et al. 2008). Therefore, several environmental conditions and geographical distances among areas at different scales may play an important role in floristic variations across the Amazon region.

Edaphic and climatic factors, such as precipitation and drought regimes are regarded as important factors responsible for high plant diversity in Amazon, resulting in high dissimilarity between plant communities (Gentry 1988, Coronado et al. 2009), which in some cases has also been associated to topographic variations (Tuomisto \& Ruokolainen 1997, Poulsen et al. 2006, Coronado et al. 2009). There is a gradient in floristic composition that contrasts the Eastern and central regions of the Amazon (Guiana shield and Brazil), that are geologically older with poorer soils, with Western areas where sediments from the Andes result in more fertile soils (Quesada et al. 2009).
The Amazonas State occupies a large area, with approximately 1.5 million square kilometers in extent and holds large heterogeneity in natural ecosystems. Studies in terra firme forest near Manaus, Amazonas State, have found trees with diameter $\geq 10 \mathrm{~cm}, 239$ species and Shannon's diversity index of 5.01, in one-ha inventoried plots, revealing a high diversity in such forests (Oliveira \& Amaral 2004, Oliveira et al. 2008). Thus, there is an increasing demand for ecological studies, specially on the floristic composition and its variation across regions, which can back up actions for restoration, conservation and management of natural resources, that can prevent the extinction of rare and low-abundant species, and could contribute to the maintenance of the high diversity of species and habitats in several areas around this vast and complex Amazon region.

The aim of this paper is to describe and analyse the floristic composition and diversity in the large survey of 151 -ha plots in terra firme tropical rainforest at the Embrapa Experimental site, in central Amazon, Manaus, Amazonas State and to compare their floristic composition with other nine plots spread over the Amazonas State, by analysing the influence of the geographical distance on the floristic similarity between plots across Amazonas State, Brazil.

\section{MATERIALS AND METHODS}

Study site: The study area is located in a terra firme dense forest of Central Amazon, at the Embrapa Experimental site, Central Amazon, Manaus, Amazonas state, Brazil, with a total area of $400 \mathrm{ha}$. This was subdivided into one-ha permanent plots, belonging to the forest management project developed in the Amazon region in Brazil. The climate is tropical, type "Am" (Koppen classification), with a mean annual rainfall ranging from 1355 to 2 $839 \mathrm{~mm}$. The mean annual temperature ranges from $25.6^{\circ} \mathrm{C}$ to $27.6^{\circ} \mathrm{C}$, with relative humidity from 84 to $90 \%$ (RADAM 1978). On a broad scale, soils are fairly homogeneous throughout the stands; heavy-textured dystrophic yellow 
latosol predominates, covered mainly by dense forest with emergent trees (IBGE 1999), but with a low degree of local variation in topographic and edaphic conditions. The upland areas are plateaus formed by Tertiary sediments that cover the largest portion of the Amazon sedimentary basin, shaped into landforms dissected in extensive interfluvial plateaus and hills (Regis 1993).

Field sampling: Fifteen 1ha sized plots were randomly chosen from the area of 400 in order to investigate the diversity, floristic composition and similarity as compared to nine other terra firme forests from the same Amazonas state. The 15 plots measured 100x100m and had their topographic position recorded as top, slope and base (Fig. 1). Nine were completely positioned in the top position according to topography; four presented a gradient in top and slope; another one stands completely in a base position and one was in the slope and base. All trees $\geq 10 \mathrm{~cm}$ dbh (diameter at breast height) were tagged and botanically classified to species level, in the survey undertaken in 2005 (Silva 2010). The botanical material was identified (APGII system) by specialists at the herbarium of the Instituto Nacional de Pesquisas da Amazonia, Manaus, by experts and specialized literature (Ribeiro et al. 1999). The names were checked with the W3tropics database from the Missouri Botanical Garden.

Twenty four plots, consisting of 15 from our present study, called "EMB" plus the plot number, together with nine plots coming from different surveys in the Amazonas State, located also in terra firme forests, were used for the floristic similarity analysis (Table 1). All plots inventoried were one-ha sized with $\mathrm{dbh} \geq 10 \mathrm{~cm}$ trees. The nine plots species list was obtained from published and unpublished surveys carried out by INPA's researchers. The coordinates of all plots were defined by their centroid.

The floristic diversity was estimated by the species richness and the Shannon-Wiener's index (Magurran 1988). The diversity and

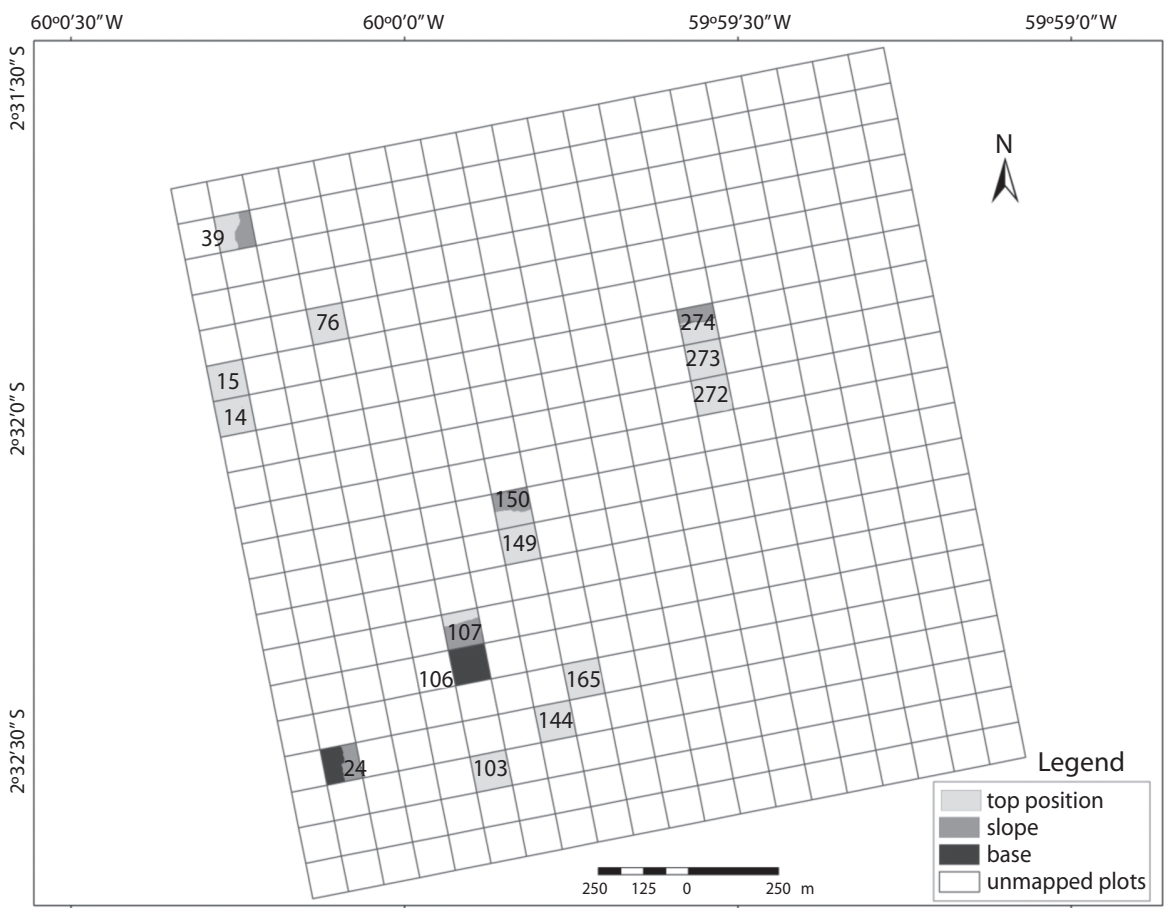

Fig. 1. Topographic position of 15 ha sized plots at Embrapa Experimental site, Manaus, Amazonas state, Brazil. 
TABLE 1

Information source for inventories in 1 ha plots with a minimum of $10 \mathrm{~cm}$ DAP, carried out in state of Amazonas, Brazil

\begin{tabular}{|c|c|c|c|}
\hline Site & Lat. & Long. & Source \\
\hline EEST & $-2^{\circ} 35^{\prime} 53.77^{\prime \prime}$ & $-60^{\circ} 02^{\prime} 52.69^{\prime \prime}$ & (Matos 2006) \\
\hline IPIR & $-2^{\circ} 58^{\prime} 09.8^{\prime \prime}$ & $-59^{\circ} 54^{\prime} 18.0^{\prime \prime}$ & (Matos 2006) \\
\hline ITAP & $-2^{\circ} 33^{\prime} 30^{\prime \prime}$ & $-58^{\circ} 23^{\prime}$ & (Amaral et al. 2000) \\
\hline JURUA & $-6^{\circ} 36^{\prime}$ & $-67^{\circ} 19^{\prime} 30^{\prime \prime}$ & Not published-INPA/CPBO* \\
\hline ZFkm14 & $-2^{\circ} 35^{\prime} 32,2^{\prime \prime}$ & $-60^{\circ} 06^{\prime} 40^{\prime \prime}$ & (Sposito et al. 2007) \\
\hline ZF2B & $-2^{\circ} 35^{\prime} 45^{\prime \prime}$ & $-60^{\circ} 12^{\prime} 40^{\prime \prime}$ & (Formiga 2004) \\
\hline ZF2P & $-2^{\circ} 35^{\prime} 45^{\prime \prime}$ & $-60^{\circ} 12^{\prime} 40^{\prime \prime}$ & (Oliveira et al. 2008) \\
\hline ZF2V & $-2^{\circ} 35^{\prime} 45^{\prime \prime}$ & $-60^{\circ} 12^{\prime} 40^{\prime \prime}$ & (Oliveira \& Amaral 2004) \\
\hline ZFkm37 & $-2^{\circ} 26^{\prime} 22.6^{\prime \prime}$ & $-59^{\circ} 47^{\prime} 48.5^{\prime \prime}$ & (Sposito et al. 2007) \\
\hline EMB14 & $-2^{\circ} 31.99^{\prime}$ & $-60^{\circ} 0.25$ & This paper \\
\hline EMB15 & $-2^{\circ} 31.94^{\prime}$ & $-60^{\circ} 0.26^{\prime}$ & This paper \\
\hline EMB24 & $-2^{\circ} 32.52^{\prime}$ & $-60^{\circ} 0.09^{\prime}$ & This paper \\
\hline EMB39 & $-2^{\circ} 31.71^{\prime}$ & $-60^{\circ} 0.25^{\prime}$ & This paper \\
\hline EMB76 & $-2^{\circ} 31.85^{\prime}$ & $-60^{\circ} 0.11$ & This paper \\
\hline EMB103 & $-2^{\circ} 32.53^{\prime}$ & $-59^{\circ} 59.86^{\prime}$ & This paper \\
\hline EMB106 & $-2^{\circ} 32.37^{\prime}$ & $-59^{\circ} 59.9^{\prime}$ & This paper \\
\hline EMB107 & $-2^{\circ} 32.31^{\prime}$ & $-59^{\circ} 59.91^{\prime}$ & This paper \\
\hline EMB144 & $-2^{\circ} 32.45^{\prime}$ & $-59^{\circ} 59.77^{\prime}$ & This paper \\
\hline EMB149 & $-2^{\circ} 32.18^{\prime}$ & $-59^{\circ} 59.82^{\prime}$ & This paper \\
\hline EMB150 & $-2^{\circ} 32.13^{\prime}$ & $-59^{\circ} 59.83^{\prime}$ & This paper \\
\hline EMB165 & $-2^{\circ} 32.39^{\prime}$ & $-59^{\circ} 59.73^{\prime}$ & This paper \\
\hline EMB272 & $-2^{\circ} 31.96^{\prime}$ & $-59^{\circ} 59.53^{\prime}$ & This paper \\
\hline EMB273 & $-2^{\circ} 31.91^{\prime}$ & $-59^{\circ} 59.54^{\prime}$ & This paper \\
\hline EMB274 & $-2^{\circ} 31.85^{\prime}$ & $-59^{\circ} 59.55^{\prime}$ & This paper \\
\hline
\end{tabular}

* INPA/CPBO (Instituto Nacional de Pesquisas da Amazonia/Coordenação de Pesquisas em Botânica).

floristic composition was analysed by using Mata Nativa software (Cientec 2006). The floristic similarity analysis was done by using the Sorensen's similarity index, and the Cluster analysis was carried out with the unweighted pair-group average (UPGMA) method (Legendre \& Legendre 1998). The PAST 1.94 software was used for these analyses (Hammer et al. 2001). To measure the influence of geographical distance on floristic composition between the 24 sites, and within 15 EMB plots and within the nine other plots alone, a Mantel test (r) (Fortin \& Dale 2005) was applied. The test was based on two matrixes; one of geographical distance (Euclidean distance) and another one of floristic distance between plots (dissimilarity). A Permutation test was applied for significance of the Mantel coefficients. The Mantel test was performed using Passage 1 software (Rosenberg 2005).

\section{RESULTS}

A total of 8771 individuals distributed in 264 species and 51 families were identified in 15 one-ha sized plots, at Embrapa Experimental site. The eight families presenting the highest species richness, in decreasing order were: Fabaceae (Fabaceae-Faboideae (22spp.), Fabaceae-Mimosoideae (22) and FabaceaeCaesalpinioideae (10)), Sapotaceae (22), Lecythidaceae (15), Lauraceae (13), Moraceae 
(11), Euphorbiaceae (11), Annonaceae (10) and Chrysobalanaceae (9) (Fig. 2.A). Fabaceae, Sapotaceae and Lecythidaceae families contributed with $34 \%$ of the species richness at the sampled plots. The five families with the largest number of individuals were: Burseraceae, Sapotaceae, Lecythidaceae, Chrysobalanaceae and Moraceae, amounting to $46 \%$ of all individuals, Fig. 2.B.

Out of 264 species recorded, the ten most abundant were: Protium hebetatum Daly (1 037

A

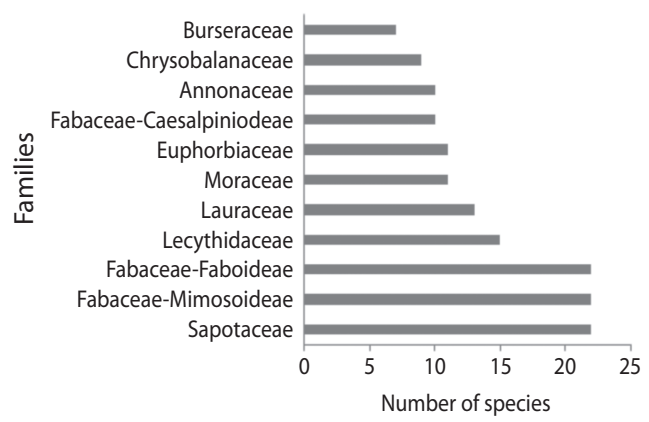

individuals), Eschweilera coriacea (DC.) S.A. Mori (471), Licania oblongifolia Standl. (310), Pouteria minima T.D.Penn. (293), Ocotea cernиа (Nees) Mez s.l. (258), Scleronema micranthum Ducke (197), Eschweilera collina Eyma (176), Licania apelata (E.Mey.) Fritsch (172), Naucleopsis caloneura (Huber) Ducke (170) and Psidium araca Raddi (152) (Fig. 3). These species represent $36.5 \%$ of the total number of individuals, and only Protium hebetatum, Burseraceae had $11.8 \%$ of the relative abundance.

B

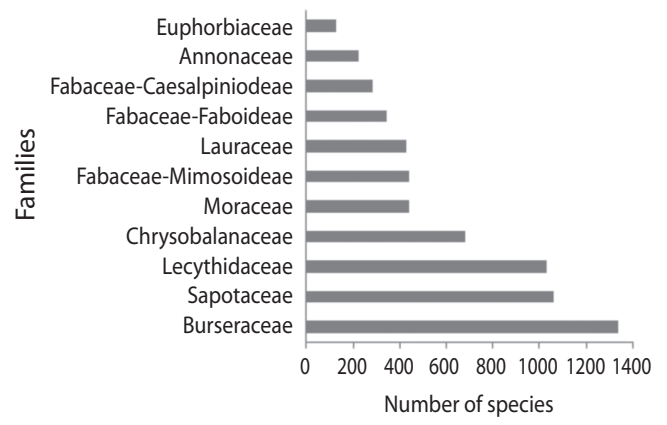

Fig. 2. (A) Families with more number of species; (B) Families with more number of individuals identified at 151 ha sized plots at Embrapa Experimental site, Manaus, Amazonas state, Brazil.

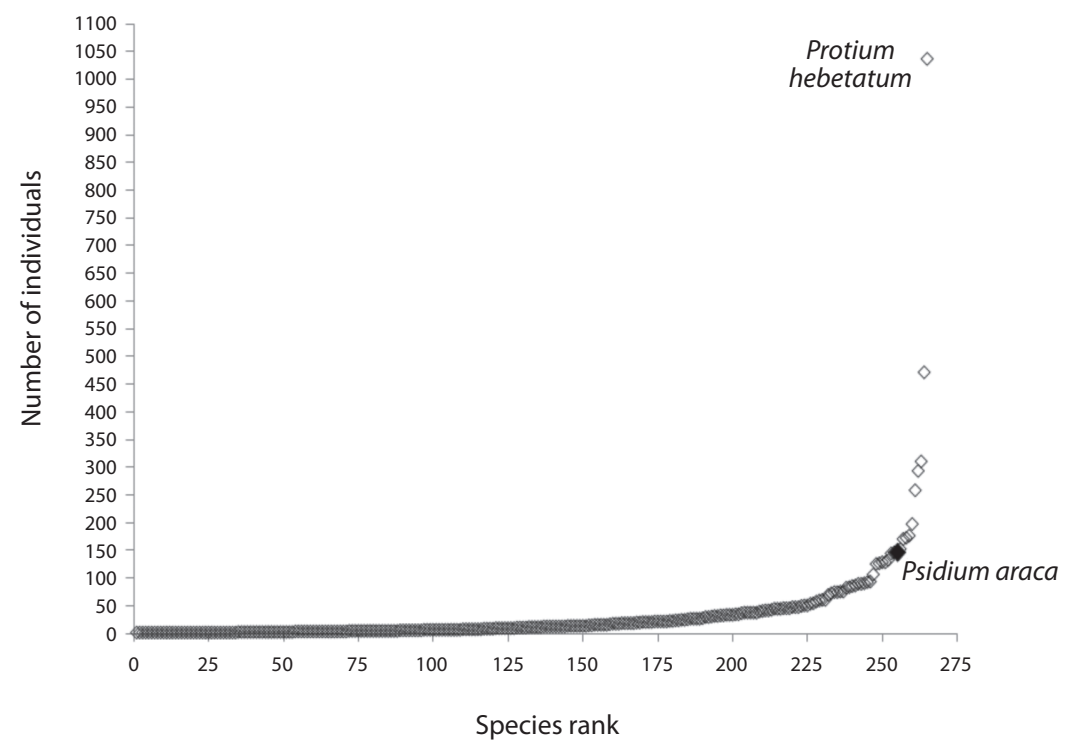

Fig. 3. Species ranked by the number of individuals, highlighting the most abundant ones among Pisidium araca and Protium hebetatum at Embrapa Experimental site, Manaus, Amazonas state, Brazil. 
The number of individuals per plot ranged from 495 to 682 , with SD equal to 56.4 (Table 2), showing a great variability in the abundance of species measured in all the 15 plots of the study area. Figure 4 shows the species distribution by class of number of individuals within each sampled plot. Thirtyfour species (13\%) appeared only once when we summed the abundances over all 15 plots, showing the large occurrence of rare species. Plots 39 and 165 had no occurrence of species with only one individual.

The Shannon-Wiener's diversity index varied between 3.8 and 4.22 among the 15 plots (Table 2).

Our floristic similarity comparison between the 15 sampled plots used in this paper and the other nine plots (Table 1), all terra firme tropical rainforests is presented in Fig. 5 . We can see two major groups formed by our 15 plots identified as "EMB" (group-1) and the other plots, (group-2), but for the "ZF2B" and "JURUA" plots that were different from the two groups. The two groups shared low species percentages of about $25 \%$. The 15 "EMB" plots group had higher values of similarity (higher than 60\%) compared to the other group, which
TABLE 2

Abundance and diversity measures at each sampled plot in the Embrapa Experimental site, Manaus, Amazonas State, Brazil

\begin{tabular}{ccccc} 
Plots & N & S & H' & A \\
14 & 538 & 126 & 4.22 & 51.20 \\
15 & 519 & 122 & 4.19 & 49.67 \\
24 & 528 & 109 & 3.99 & 44.09 \\
39 & 583 & 121 & 4.14 & 46.32 \\
76 & 620 & 129 & 4.21 & 48.86 \\
103 & 530 & 107 & 3.9 & 38.84 \\
106 & 495 & 112 & 4.07 & 44.43 \\
107 & 626 & 128 & 4.2 & 49.28 \\
144 & 607 & 104 & 3.8 & 35.60 \\
149 & 628 & 118 & 3.87 & 42.96 \\
150 & 682 & 140 & 4.26 & 52.83 \\
165 & 649 & 101 & 3.99 & 33.03 \\
272 & 571 & 105 & 3.99 & 37.26 \\
273 & 560 & 108 & 3.97 & 39.26 \\
274 & 635 & 114 & 3.92 & 39.45 \\
\hline
\end{tabular}

$\mathrm{N}=$ total number of individuals; $\mathrm{S}=$ number of species; H'=Shannon-Wiener index; $\alpha=$ Fisher's alpha.

had approximately half of the plots (5) grouping in a level close to 40 percent.

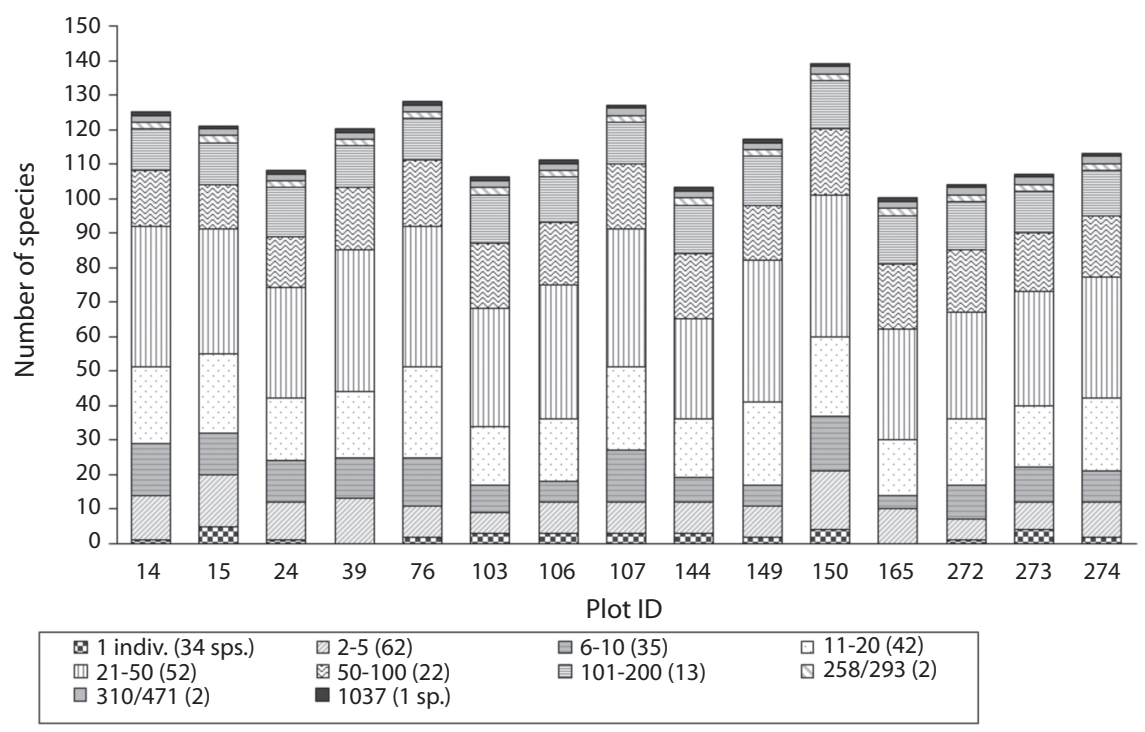

Fig. 4. Occurrence of species by class of number of individuals at each inventoried plots, summed in all 15 plots at the Embrapa Experimental site, Manaus, Amazonas state, Brazil. 


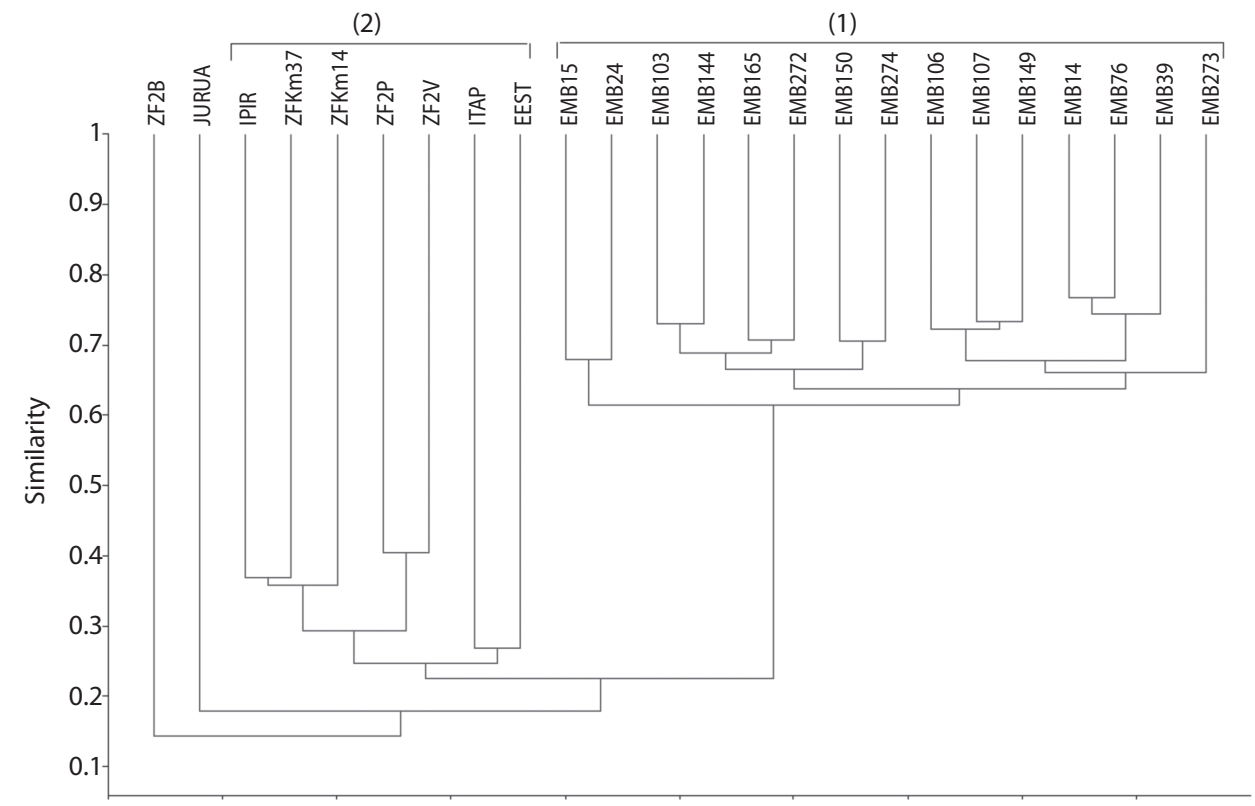

Fig. 5. Dendrogram of 24 1-ha sized plots in tropical rainforests in the state of Amazonas, Brazil, using Sorensen's similarity index, clustered by the unweighted pair-group average (UPGMA) method. The numbers (1) and (2) represent two major groups and numbers in the branches stand for the plots identification.

For the 15 EMB plots the distances between pair of plots varied from a minimum of $100 \mathrm{~m}$ to a maximum of $1657 \mathrm{~m}$ (from "EMB39" to "EMB103" plot). The other nine plots had larger distances between pairs, varying from a minimum of $100 \mathrm{~m}$ to a maximum of 918km (from "JURUA" to "ITAP" plots). The Mantel test, carried out to study the association between differences in species composition and geographic distances among plots, showed positive and significant correlation when all sites were analysed (Fig. 6, R=0.3627, p<0.01). For our $15 \mathrm{EMB}$ plots we also found a significant correlation $(\mathrm{R}=0.4012, \mathrm{p}<0.001)$. However, the nine plots used to compare with our 15plots, showed no significant correlation between floristic similarity and geographical distances, when analysed alone $(\mathrm{R}=0.3049, \mathrm{p}>0.05)$.

\section{DISCUSSION}

Floristic composition and diversity: Alike many studies carried out in Amazonian terra firme forests, our study area had most species concentrated in few families. Also, the larger number of individuals was concentrated in a small number of species just as found in other papers (Rankin-de-Merona 1987, Phillips et al. 1994, Milliken 1998, Amaral et al. 2000, ter Steege 2000, Lima Filho et al. 2001, Oliveira \& Amaral 2004, Oliveira et al. 2008). The ten most abundant species had $36.5 \%$ of the total number of individuals identified and were found along the 15 sampled plots, with $100 \%$ of frequency. Besides, the families with the highest species richness were not the ones which had the largest number of individuals (Amaral et al. 2000). Burseraceae with low species richness, not included amongst the families presenting the highest species richness had the largest number of individuals. However, we found other studies showing that there might be a relation between richness and abundance in families (Tello 1995, Oliveira et al. 2008). The predominance of families in terra firme tropical rainforests in central Amazonian, 


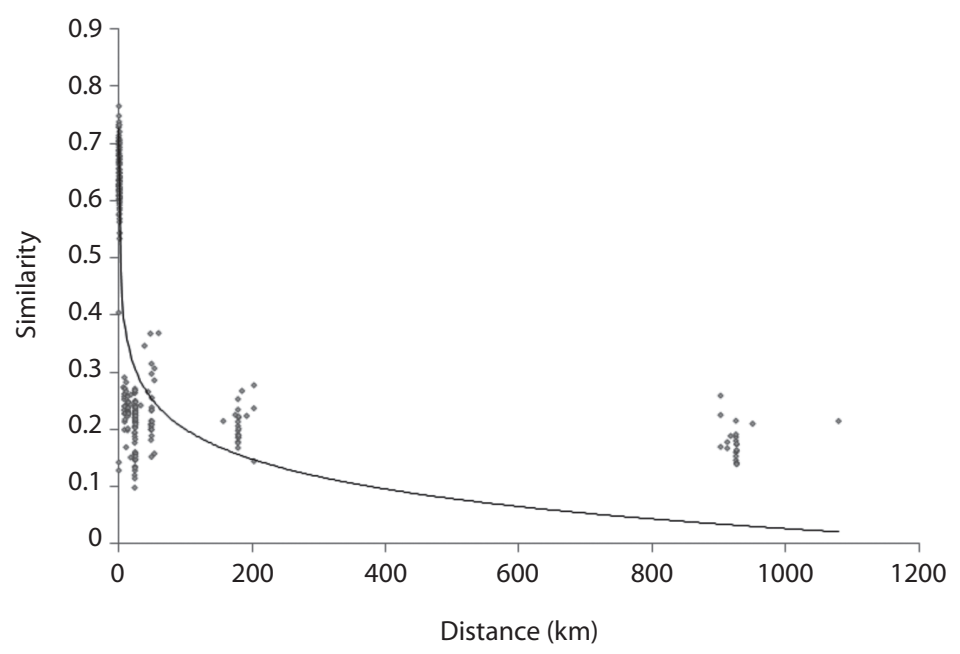

Fig. 6. Floristic similarity (Sorensen index) between pairs of plots over geographical distances.

such as Sapotaceae, Lecythidaceae and Burseraceae (Oliveira \& Amaral 2005, Oliveira et al. 2008, Coronado et al. 2009) and also in the present study, is noteworthy. This information has been helpful in dynamic studies aiming to measure the changes in composition and structure in forest communities by several sources of changes.

It is also important to highlight the occurrence of $36 \%$ of the species having up to five individuals considering all 15 sampled plots. The occurrence of rare species has been recorded by several studies (Prance et al. 1976, Oliveira \& Amaral 2004, 2005, Caiafa et al. 2009). Hubbell et al. (2001) cited that one possible reason for the rarity in tropical forests may be that rare tree species suffer stronger density-dependent effects than common species do, resulting in a low number of individuals. Also, in the presence of a resource gradient, species can evolve in order to occupy different positions in these gradients, resulting in variations on the abundance distribution (Comita $e t$ al. 2007, Alves \& Miranda 2008). In the present paper, we saw some degree of variability amongst plots, specially when we analysed the species distribution by their classes of number of individuals, especially when we compared plots $150,24,103$ and 165 to the other ones, in small abundance classes. These plots show local variability in topography, which may have contributed to the large occurrence of rare species due to environmental heterogeneity and possible species' adaptation to such variability. Future studies could confirm these statements, since they were not considered in the present study.

The Shannon-Wiener's diversity index registered for Amazonian forests generally ranges from 3.83 to 5.85 , which are considered high values (Knight 1975, Oliveira \& Mori 1999). Our value for the whole area was of 4.49 within the range of high diverse forest. From the previous knowledge of the study area we perceived a gradient of diversity in decreasing order, ranging from the clayey plots $(150,14$, $15,76)$ to the sandy ones $(24,106,272,273$, 274). Edaphic heterogeneity seems to play an important role in the maintenance of the high diversity in tropical forests with tree species distribution influenced by soil characteristics (Torres et al. 1997, Tuomisto \& Ruokolainen 1997, Clark 2002, Martins et al. 2003, Ruokolainen et al. 2007, Pinto et al. 2008).

Floristic similarity: This condition was compared in all the 24 locations showing mainly two groups of plots. Overall, our 15 
"EMB" plots shared more than 0.6 of their species, while the comparison within group-1, revealed that some plots are grouped by their geographical proximity, and where closer plots shared more species with more than 0.7 , such as plots14-76 and 103-144, which were all at the highest position according to the topography. Our plots showed higher values when compared with Oliveira \& Amaral (2004), who found values for Sorensen's index that ranged from 0.28 to 0.36 among 20 plots in terra firme forests near Manaus (with maximum distance of $200 \mathrm{~m}$ from each other), but falls in the range of findings by Gama et al. 2005 and Coronado et al. (2009), who also found high similarity values. This fact was ratified by the Mantel test, which showed a significant positive correlation between geographical distances and species composition, i.e., the shorter the geographical distance, the more similar the plots were. However, some EMB plots seem to be clustered regardless of their proximity and of their topographic position, such as plots 15-24. Other factors might influence such cluster, which need to be investigated in future studies.

It seems that the environmental heterogeneity and distance played effect in separating plots, which could be observed for the "ZF2B" and "JURUA" plots, once the former plot is located at the base position in the topography and the "JURUA" is the farthest plot located in other watershed, probably having different features when compared to the others. Despite the positive correlation between geographical distance and species composition, the Mantel coefficient was not significant. Through the dendrogram analysis, we could better see the tendency of adjacent plots sharing more species, like the plots ZF2P and ZF2V, which are close to each other (100m apart).

When all the 24 plots were included in the Mantel test, a positive and significant correlation was found $(\mathrm{R}=0.3627, \mathrm{p}<0.01)$, showing that plots near one another tend to be more similar in species composition, and on the other hand, distant plots tend to be less similar. Malheiros et al. (2009) when comparing plots from forests in the Amazon region found that the closer to one another, the more similar they were to each other in species composition. The local heterogeneity could explain the low similarity within group-2 and between both groups, although these values could be considered high values for Amazon region (Coronado et al. 2009). It is expected that environmentally similar sites tend to have similar floristic compositions, whereas environmentally different ones have different composition (Barrantes \& Sandoval 2009). Also, biological factors such as species dispersal and competitive abilities, herbivory, and so on, have been considered to affect the diversity in forest communities, generating several trends in alpha-diversity, which need to be better understood (Tuomisto \& Ruokolainen 2005).

In addition, our study area shows high tree diversity and calls our attention to the large occurrence of low-abundance species across the whole area and to the necessity of considering such rare species in management projects in order to prevent local extinctions. Our results fall in the range of the floristic composition and diversity's index for Amazon terra firme forests, and the comparison between our 15 plots in the present study and other nine in the Amazonas state, showed that the closer to one another the plots the more similar they are in species composition. Also, we point out that the mosaic of environments in the Amazon terra firme forests, with regional and local variations, coupled with the biological processes, may be responsible for the low similarity observed between some plots compared in this study, showing once more the importance of studies that can keep such variability, helping to understand the mechanisms that bring about and maintain the high tree diversity in tropical rainforests.

\section{ACKNOWLEDGMENTS}

We thank the Brazilian Agricultural Research Corporation (EMBRAPA) for the financial support, and the Federal University of Viçosa for the opportunity to accomplish the study and the data analysis and the 
National Council for Scientific and Technological Development (CNPq).

\section{RESUMEN}

La región amazónica es una de las más diversas áreas del mundo. Los estudios sobre la gran diversidad de bosques tropicales generan contribuciones relevantes en la comprensión de los mecanismos que originan y apoyan tal diversidad. En el presente estudio se describe la composición de las especies y la diversidad de 15 parcelas de una hectárea en el bosque denso amazónico terra firme en Brasil, y compara la similitud florística de estas parcelas con otras nueve parcelas de una hectárea. Las 15 parcelas estudiadas fueron seleccionadas al azar, en el 2005, de parcelas permanentes en el sitio experimental de Embrapa, Estado de Amazonas. La diversidad fue analizada utilizando la riqueza de especies y el índice de Shannon, así como el índice de Similitud de Sorensen; y como método de agrupación se utilizó el promedio no ponderado por grupo (UPGMA). La prueba de Mantel se llevó a cabo para estudiar si las diferencias en la composición de especies entre los sitios podrían ser explicadas por la distancia geográfica entre ellos. En general, se identificaron 8771 individuos, 264 especies y 51 familias de plantas. La mayoría de las especies se concentraron en pocas familias y pocas tenían un gran número de individuos. Las familias que presentaron la mayor riqueza de especies fueron: Fabaceae (Faboideae: 22spp, Mimosoideae: 22spp), Sapotaceae: 22spp, Lecythidaceae: 15 y Lauraceae: 13. Burseraceae tuvo el mayor número de individuos con un $11.8 \%$ del total. Las diez especies más abundantes fueron: Protium hebetatum (1 037 individuos), Eschweilera coriacea (471), Licania oblongifolia (310), Pouteria minima (293), Ocotea cernua (258), Scleronema micranthum (197), Eschweilera collina (176), Licania apelata (172), Naucleopsis caloneura (170) y Psidium araca (152), que representó un $36.5 \%$ de todos los individuos. Aproximadamente en el $49 \%$ de las especies se encontraron hasta diez individuos, mientras que el 13\% de las especies apareció sólo una vez en todas las parcelas de muestreo, lo que demuestra una alta presencia de especies raras. La zona de estudio se encuentra en un bosque con alta diversidad de especies de árboles, con un índice de diversidad de Shannon de 4.49. El dendrograma mostró dos grupos de parcelas con baja similitud entre ellas (menos de 0.25), y entre más cercanas las parcelas, más similares en composición de especies fueron (Mantel $\mathrm{R}=0.3627, \mathrm{p}<0.01)$. Las 15 parcelas en nuestra área de estudio compartieron más del 50\% de su composición de especies y representaron el grupo de parcelas con la menor distancia entre ellas. En general, nuestros resultados ponen de manifiesto la alta heterogeneidad local y regional de los ambientes de los bosques de terra firme, y la gran concurrencia de especies raras, lo cual debe ser considerado en los planes de manejo y conservación de la selva amazónica, con el fin de mantener su estructura a largo plazo.
Palabras clave: composición boscosa, Amazonía Central, ecología forestal, similitud florística, diversidad, terra firme, bosque denso de tierras altas.

\section{REFERENCES}

Alves, J.C.Z.O. \& I.S. Miranda. 2008. Analise da estrutura de comunidades arbóreas de uma floresta amazônica de terra firme aplicada ao manejo florestal. Acta Amaz. 38: 657-666.

Amaral, I.L., F.D.A. Matos \& J. Lima. 2000. Composição florística e parâmetros estruturais de um hectare de floresta densa de terra firme no rio Uatumã, Amazonia, Brazil. Acta Amaz. 30: 377-392.

Barrantes, G. \& L. Sandoval. 2009. Conceptual and statistical problems associated with the use of diversity indices in ecology. Rev. Biol. Trop. 57: 451-460.

Caiafa, A.N., S.B. Martins, J.A. Nunes \& P.V. Eisenlohr. 2009. Espécies arbóreas raras, p. 245-261. In S.V. Martins (ed). Ecologia de florestas tropicais do Brasil. Editora UFV, Universidade Federal de Viçosa, Viçosa, Brasil.

Clark, D.B. 2002. Los factores edáficos y la distribución de las plantas, p. 192-221. In M.R. Guariguatta \& G.H. Kattan (eds.). Ecología y conservación de bosques neotropicales. LUR, San José, Costa Rica.

Cientec. 2006. Software Mata Nativa 2: Sistema para Análise Fitossociológica, Elaboração de Inventários e Planos de Manejo de Florestas Nativas. Viçosa, Brasil.

Comita, L.S., R. Condit \& S. Hubbell. 2007. Developmental changes in habitat associations of tropical trees. J. Ecol. 95: 482-492.

Coronado, E.N.H., T.R. Baker, O.L. Phillips, N.C.A. Pitman, R.T. Pennington, R.V. Martınez, A. Monteagudo, H. Mogollón, N.D. Cardozo, M. Ríos, R. García-Villacorta, E. Valderrama, M. Ahuite, I. Huamantupa, D.A. Neill, W.F. Laurance, H.E.M. Nascimento, S.S. de Almeida, T.J. Killeen, L. Arroyo, P. Núnez \& L.F. Alvarado. 2009. Integrating regional and continental scale comparisons of tree composition in Amazonian terra firme forests. Biog. Discuss. 6: 1421-1451.

Ferreira, L.V. \& G.T. Prance. 1998. Species richness and floristic composition in four hectares in the Jaú National Park in upland forests in Central Amazonia. Biod. Cons. 7: 1349-1364.

Formiga, K.M. 2004. Avaliação dos parâmetros estruturais, diversidade e similaridade florística de uma floresta 
de baixio, na ZF2, reserva do Cuieiras, Amazonas, Brasil. Instituto de Tecnologia do Amazonas/UEA. (Monography), Manaus, Brasil.

Fortin, M.J \& M.R.T. Dale. 2005. Spatial analysis: A Guide for Ecologists. Cambridge University, New York, USA.

Gama, J.R.V., A.L. Souza, S.V. Martins \& D.R. Souza. 2005. Comparação entre florestas de várzea e de terra firme do Estado do Pará. Rev. Árv. 29: 607-616.

Gentry, A.H. 1988. Changes in plant community diversity and floristic composition on environmental and geographical gradients. Ann. Miss. Bot. Garden 75: 1-34.

Hammer, O., D.A.T. Harper \& P.D. Ryan. 2001. PAST: Paleontological Statistics Software Package for Education and Data Analysis. V. 1.92. Palaeontologia Eletronic.

Houghton, R.A., D.L. Skole, C.A. Nobre, J.L. Hackler, K.T. Lawrence \& W.H. Chomentowski. 2000. Annual fluxes of carbon from deforestation and regrowth in the Brazilian Amazon. Nature 301-304.

Hubbell, S.P., J.A. Ahumada, R. Condit \& R.B. Foster. 2001. Local neighborhood effects on long-term survival of Individual trees in a neotropical forest. Ecol. Res. 16: 859-875.

Instituto Brasileiro de Geografia e Estatística (IBGE).1999. Mapa digital temático de vegetação, Banco de dados Sipam, Brasil.

Knight, D.H. 1975. A phytosociological analysis of species-rich tropical forest on Barro Colorado Island, Panama. Ecol. Monog. 45: 259-28.

Legendre, P. \& L. Legendre.1998. Numerical Ecology. Elsevier, Amsterdam, The Netherlands.

Lima Filho, D.A., F.D.A. Matos, I.L. Amaral, J. Revilla, L.S. Coêlho, J.F. Ramos \& J.L. Santos. 2001. Inventário florístico de floresta ombrófila densa de terra firme, na região do Rio Urucu-Amazonas, Brasil. Acta Amaz. 31: 565-579.

Magurran, A.E. 1988. Ecological diversity and its measurement. Cambridge University, New York, USA.

Malheiros, A.F., N. Higuchi \& J. Santos. 2009. Análise estrutural da floresta tropical úmida do município de Alta Floresta, Mato Grosso, Brasil. Acta Amaz. 39: 539-548.

Martins, S.V., N.R.S. Silva, A.L. Souza \& J.A.A. Meira Neto. 2003. Distribuição de espécies arbóreas em um gradiente topográfico de Floresta Estacional Semidecidual em Viçosa, MG. Scie. For. 64: 172-181.

Matos, F.D.A. 2006. Estimativa de biomassa e carbono em floresta ombrófila densa de terra firme na Amazônia Central, Manaus-AM, Brasil, por meio de dados de satélites de média e alta resolução espacial.Tese de Doutorado, Universidade Federal do Paraná, Curitiba-PR, Brasil.

Milliken, W. 1998. Structure and composition of one hectare of central Amazonian terra firme Forest. Biotropica 30: $530-537$.

Oliveira, A.A. \& S.A. Mori.1999. A central Amazonian terra firme forest. I. High tree species richness on poor soils. Biod. Cons. 8: 1219-1244.

Oliveira, A.N. \& I.L. Amaral. 2004. Florística e fitossociologia de uma floresta de vertente na Amazônia Central, Amazonas, Brasil. Acta Amaz. 34: 21-34.

Oliveira, A.N. \& I.L. Amaral. 2005. Aspectos florísticos, fitossociológicos e ecológicos de um sub-bosque de terra firme na Amazônia Central, Amazonas, Brasil. Acta Amaz. 35: 1-16.

Oliveira, A.N., I.L. Amaral, M.B.P. Ramos, A.D. Nobre, L.B. Couto \& R.M. Sahdor. 2008. Composição e diversidade florístico-estrutural de um hectare de floresta densa de terra firme na Amazonia Central, Amazonas, Brasil. Acta Amaz. 38: 627-642.

Plano Amazônia Sustentável (PAS). 2008. Governo Federal (also available on-line: http://www.mma.gov.br)

Phillips, O.L., P. Hall, A.H. Gentry, S.A. Sawyer \& R. Vásquez. 1994. Dynamics and species richness of tropical rain forests. Proc. Nat. Acad. Sci. 91: 2805-2809.

Pinto, S.I.C., S.V. Martins, N.F. Barros, H.C.T. Dias \& S.H. Kunz. 2008. Influence of environmental variables on the shrub and tree species distribution in two Semideciduous Forest sites in Viçosa, Minas Gerais, Brazil. Rev. Biol. Trop. 56: 1557-1569.

Pitman, N.C.M., J.W. Terborg, S.R. Silvan, P.V. Nunes, D.A. Neil, C.E. Ceron \& W.A. Palacios. 2001. Dominance and distribution of tree species in upper Amazonia terra firme. Ecology 82: 2101-2117.

Poulsen, A.D., H. Tuomisto \& H. Balslev. 2006. Edaphic and floristic variation within a 1-ha plot of lowland Amazonian rain forest. Biotropica 38: 468-478.

Prance, G.T., W.A. Rodrigues \& M.F. Silva. 1976. Inventário florestal de um hectare de mata de terra firme, km 30 da estrada Manaus-Itacoatiara. Acta Amaz. 6: $9-35$ 
Quesada, C.A., J. Lloyd, M. Schwarz, T.R. Baker, O.L. Phillips, S. Patiño, C. Czimczic, M.G. Hodnett, R. Herrera, A. Arneth, G. Lloyd, Y. Malhi, N. Dezzeo, F.J. Luizão, A.J.B. Santos, J. Schmerler, L. Arroyo, M. Silveira, N. Priante Filho, E.M. Jimenez, R. Paiva, I. Vieira, D.A. Neill, N. Silva, M.C. Peñuela, A. Monteagudo, R. Vásquez, A. Prieto, A. Rudas, S. Almeida, N. Higuchi, A.T. Lezama, G. López-Gonzalez, J. Peacock, N.M. Fyllas, E. Alvarez Dávilla, T. Erwin, A. di Fiore, K.J. Cao, E. Honorio, T. Kileen, A. Peña Cruz, N. Pitman, P. Nuñez Vargas, R. Salomão, J. Terborgh \& H. Ramirez. 2009. Regional and large-scale patterns in Amazon forest structure and function are mediated by variations in soil physical and chemical properties. Biog. Discuss. 6: 3993-4057.

RADAM. 1978. Programa de Integração Nacional. Levantamentos de Recursos Naturais. Manaus. DNPM, Ministério das Minas e Energia. Brasilia-DF, Brazil.

Rankin-de-Merona, J.M. 1987. Estudos populacionais de árvores em florestas fragmentadas e as implicações para a conservação In Situ das mesmas na floresta tropical da Amazonia central. IPEF 35: 47-59.

Regis, W.D.E. 1993. Unidades de Relêvo, p.39-45. In S.S. Caldeiron (ed.). Recursos Naturais e Meio Ambiente: Uma visão do Brasil. Fundação Instituto Brasileiro de Geografia e Estatística-IBGE, Rio de Janeiro, Brasil.

Ribeiro, J.E.L.S., B.W. Nelson, M.F. Silva, L.S.S. Martins \& M. Hopkins. 1999. Reserva florestal ducke- diversidade e composição da flora vascular. Acta Amaz. 24: 19-30.

Rosenberg, M.S. 2005. Passage 1 (Pattern Analysis, Spatial Statistics, and Geographic Exegesis). V.1.1. Arizona State University.

Ruokolainen, K., H. Tuomisto, M.J. Maciá, M.A. Higgins \& M. Y-Hallas. 2007. Are floristic and edaphic patterns in Amazonian rain forests congruent for 4 trees, pteridophytes and Melastomataceae? J. Trop. Ecol. 23: $13-25$.
Silva, K.E. 2010. Florística e estrutura espacial: 15 hectares de parcelas permanentes na floresta densa de terra firme na Amazônia Central. Ph. D. Thesis, Federal University of Viçosa, Viçosa-MG, Brasil.

Sposito, T.C., T.I. Matzer, I.L. Amaral, A.C. Oliveira, M. Horta, D.A. Clark \& D.B. Clark. 2007. Dynamic and structure of tropical forest in South and Central América: an across-site analyses of one hectare plots, p.23-30. In The third TEAM network science meeting. Panamá. The tropical ecology assessment and monitoring network. Panamá, Panamá.

Tello, J.C.R. 1995. Aspectos fitossociológicos das comunidades vegetais de uma toposseqüência da Reserva Florestal Ducke do INPA. Tese de Doutorado, Instituto Nacional de Pesquisas da Amazônia/Universidade Federal do Amazonas, Manaus, Amazonas, Brasil.

ter Steege, H., D. Sabatier, H. Castellanos, T.V. Andel, J. Duivenvoorden, A.A. Oliveira, R. Ek, R. Lilwah, P. Maas \& S. Mori. 2000. An analysis of the floristic composition and diversity of Amazonian forests including those of the Guiana Shield. J. Trop. Ecol. 16: 801-828.

ter Steege, H., N.C.A. Pitman, O.L. Phillips, J. Chave, D. Sabatier, A. Duque, J.F. Molino, M.F. Prévost, R. Spichiger, H. Castellanos, P.V. Hildebrand \& R. Vásquez. 2006. Continental-scale patterns of canopy tree composition and function across Amazonia. Nature 443: 444-447.

Torres, R.B., F.R. Martins \& L.S. Kinoshita. 1997. Climate, soil and tree flora relationships in forests in the state of São Paulo, southeastern Brazil. Rev. Bras. Bot. 20: 41-49.

Tuomisto, H. \& K. Ruokolainen. 1997. The role of ecological knowledge in explaining biogeography and biodiversity in Amazonia. Biodivers. Conserv. 6: 347-357.

Tuomisto, H. \& K. Ruokolainen. 2005. Environmental heterogeneity and the diversity of pteridophytes and Melastomataceae in Western Amazonia. Biol. Skr. 55: $37-56$. 